\title{
Expression of Estrogen Receptor- $\alpha$ and Survival in Advanced-stage Non-small Cell Lung Cancer
}

\author{
MARIUS LUND-IVERSEN ${ }^{1,2}$, HELGE SCOTT ${ }^{1,2}$, ERIK H. STRØM ${ }^{1}$, NOAH THEISS $^{3}$, \\ ODD TERJE BRUSTUGUN ${ }^{4}$ and BJøRN H. GRøNBERG ${ }^{5,6}$ \\ ${ }^{1}$ Department of Pathology, Oslo University Hospital, Oslo, Norway; \\ ${ }^{2}$ Institute of Clinical Medicine, University of Oslo, Oslo, Norway; \\ ${ }^{3}$ Ventana Medical Systems, Tucson, AZ, U.S.A.; \\ ${ }^{4}$ Section of Oncology, Drammen Hospital, Vestre Viken Hospital Trust, Drammen, Norway; \\ ${ }^{5}$ Department of Clinical and Molecular Medicine, NTNU, \\ Norwegian University of Science and Technology, Trondheim, Norway; \\ ${ }^{6}$ The Cancer Clinic, St. Olav's Hospital, Trondheim University Hospital, Trondheim, Norway
}

\begin{abstract}
Background/Aim: The favorable prognosis of women with non-small-cell lung cancer (NSCLC) compared to men might be explained by sex hormone-related mechanisms. We investigated whether this observation could be explained by the expression of estrogen receptor-alpha (ER- $\alpha)$ in tumor tissue. Materials and Methods: Archived, formalin fixed, paraffin embedded tumor tissue samples were retrospectively analyzed for nuclear expression of $E R-\alpha$ with immunohistochemistry. Results: Biopsies from 222 patients were analyzed. Twenty-three percent were ER- $\alpha$ positive. Fifty-four percent of the patients were men and $46 \%$ of the tumors were adenocarcinomas. One hundred-nine (49\%) patients received pemetrexed and carboplatin and $113(51 \%)$ received gemcitabine and carboplatin. Females with ER- $\alpha$ positive tumors who received $P C$ had a substantial survival benefit over all other groups (20 vs. 4.6 months; $p=0.003$ ). Conclusion: ER- $\alpha$ is an independent prognostic factor in advanced NSCLC and might also be a predictive factor for response to pemetrexed/carboplatin in women.
\end{abstract}

Several studies have shown that women with non-small-cell lung cancer (NSCLC) have more favorable outcomes than

This article is freely accessible online.

Correspondence to: Marius Lund-Iversen, Department of pathology, Oslo University Hospital, PO Box 4950 Nydalen, N-0424 Oslo, Norway. Tel: +47 41416894, e-mail: Marius@lund-iversen.com

Key Words: Prognostic factor, immunohistochemistry, first-line chemotherapy, gender difference, sex hormones, estrogen receptor, palliative chemotherapy. men in all stages of the disease (1-3). The reason is unclear, but the role of sex hormones has been proposed as a possible explanation. Estrogen receptors (ER) are expressed in many lung tumors (4-6), and studies indicate that estrogen influences the development of lung cancer $(7,8)$. Hormone replacement therapy appears to increase mortality in NSCLC among women (8), and there are data suggesting that estrogen activates lung adenocarcinoma cell lines derived from women, but not from men $(9,10)$. Expression of estrogen receptors has been recognized as a prognostic factor in NSCLC (11), but the results are not consistent. Some studies have shown positive and negative prognostic values of ER depending on gender and stage of disease $(5,6,12$ 14). Possible reasons for the inconsistent results are differences in the study design and patient selection. Some authors analyzed ER- $\alpha(6,15-17)$ and others ER- $\beta(5,12-$ $15,17,18)$. There are also several isoforms of ER- $\beta$ (11) and some have analyzed expression of ER in the cytoplasm (6, $14,15,18)$ while others have analyzed nuclear expression $(6,12,13,17)$. Most authors have analyzed patients with lower stage disease treated with either surgery or curative radiotherapy $(6,13-16,18)$. Only few patients with advanced disease have been included $(12,15,18)$.

Most patients with advanced NSCLC will receive platinum-doublet chemotherapy (19). Pemetrexed in combination with a platinum-compound is one of the recommended regimens for patients with non-squamous NSCLC. Previous reports have shown a survival benefit among women treated with pemetrexed combined with carboplatin (PC) compared to gemcitabine combined with carboplatin (GC) $(20,21)$. In this study we aimed to investigate the relations between ER- $\alpha$ expression, gender, treatment and survival in advanced NSCLC. 


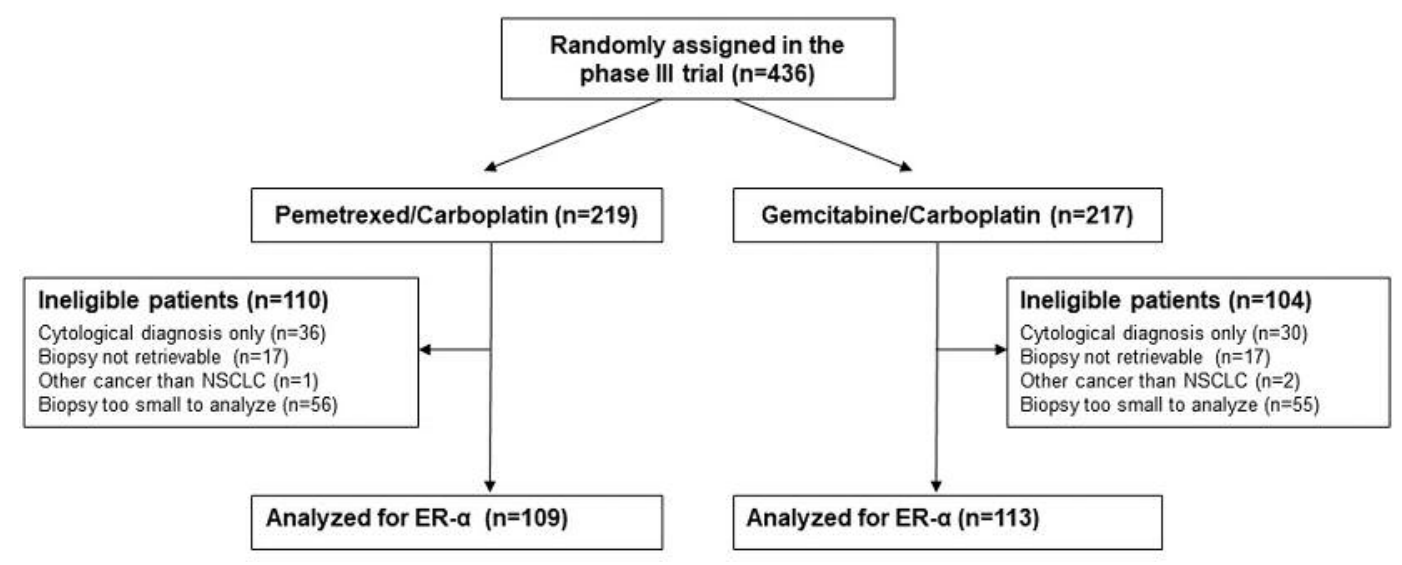

Figure 1. Patient selection scheme.

\section{Materials and Methods}

Materials. In the period May 2005 - July 2006 the Norwegian lung cancer study group conducted a phase III trial in advanced NSCLC where carboplatin was combined with either pemetrexed or gemcitabine (20). Tissue blocks from 222 participants in this study were eligible for ER- $\alpha$ investigation (Figure 1). The baseline characteristics, study chemotherapy and the post-study systemic therapy administered are listed in Table I.

All tumor material was derived from core biopsies or forceps biopsies. The area of the biopsies ranged from 0.8 to $1.2 \mathrm{~mm}^{2}$.

Immunohistochemical assays. $4 \mu \mathrm{m}$ sections were cut and placed on Superfrost Plus slides (Menzel-Glaser, Braunschweig, Germany). The slides were pretreated with Cell Conditioning 1 (Ventana Medical Systems, Inc, (VMSI), catalog number 950-124). Staining was performed on Ventana Bench Mark XT automated slide strainer with anti-Estrogen receptor (clone SP1) rabbit monoclonal primary antibody (VMSI, catalog number 790-4324) with ultra-view universal DAB detection kit (VMSI, catalog number 760-500). The SP1 clone is directed against an epitope on ER- $\alpha$ located in the nucleus. A previously confirmed ER positive carcinoma was used as a positive control. Other specimens were incubated with rabbit immunoglobulin under the same conditions as negative controls.

Assessment of ER- $\alpha$ status. The authors MLI, HS and EHS examined $10 \%$ of the slides individually and after establishment of inter-rater reliability MLI examined the remaining slides. ER- $\alpha$ was chosen in order to be able to compare our results with those of other studies $(6,13,15-17,22)$, and because there was experience with this clone from routine diagnostics. Based on previous studies on breast cancer (23) and common practice in breast carcinoma, nuclear staining was evaluated as present or absent. Tumors with $>1 \%$ positive nuclei were considered positive. Scoring of cytoplasmic staining was not performed. Photomicrographs with typical staining patterns are shown in Figure 2.

Ethics approval and consent to participate. Approval was granted by the Regional committee for medical and health research ethics in Central Norway. Reference number: 196-04. The committee granted us permission to conduct the biomarker study without asking patients for consent since almost all patients had deceased by the time we conducted the study.

Statistical analyses. Survival was calculated using the Kaplan-Meier method and the data were compared using the log-rank test. Hazard ratio (HR) was calculated with the cox proportional hazard method. To confirm subgroup analyses (as appropriate) we used interaction tests and for group comparisons we used the Chi-square test. $p<0.05$ was defined as the statistical significance level.

\section{Results}

ER- $\alpha$ status and patient characteristics. Immunohistochemical staining of nuclear ER- $\alpha$ in $>1 \%$ of tumor cells was identified in $50 / 222$ patients $(23 \%)$. There were no statistically significant differences in the proportion of ER- $\alpha$ positive tumors depending on gender (men: $20 \%$, women: $25 \% ; p=0.37$ ); stage of disease (IIIB: 22\%; IV: 23\%; $p=0.88$ ); performance status (PS 0-1: 25\%, PS 2: 15\%; $p=0.12$ ); smoking history (neversmokers: $12 \%$, smokers: $23 \%$; $p=0.27$ ); or between squamous cell carcinomas and adenocarcinomas (SCC: 18\%, ADC: $26 \%$; $p=0.25)$. There were no significant differences in baseline characteristics between patients with ER- $\alpha$ negative and those with ER- $\alpha$ positive tumors (Table I).

Among males with ER- $\alpha$ positive tumors, we found more patients with PS 0 in the pemetrexed and carboplatin arm (55\% vs. $0 \% ; p=0.007)$. There were no significant differences in baseline characteristics between the ER- $\alpha$ positive tumors in males versus females (Table II).

Survival analyses. Final survival data for the present study were collected five years after study enrolment was completed. At that time, 7 (3\%) patients were alive.

Survival curves and results from univariate analyses are shown in Figure 3 and Table III respectively. Patients with 
Table I. Baseline characteristics and treatment.

\begin{tabular}{|c|c|c|c|c|c|c|c|c|}
\hline & \multicolumn{2}{|c|}{$\begin{array}{l}\text { ER- } \alpha \text { negative } \\
\quad(\mathrm{n}=172)\end{array}$} & \multicolumn{2}{|c|}{$\begin{array}{l}\text { ER- } \alpha \text { positive } \\
\quad(\mathrm{n}=50)\end{array}$} & \multicolumn{2}{|c|}{$\begin{array}{l}\text { All patients analyzed } \\
\text { for ER status }(n=222)\end{array}$} & \multicolumn{2}{|c|}{$\begin{array}{l}\text { Excluded patients } \\
\qquad(\mathrm{n}=214)\end{array}$} \\
\hline & $\mathrm{n}$ & $\%$ & $\mathrm{n}$ & $\%$ & $\mathrm{n}$ & $\%$ & $\mathrm{n}$ & $\%$ \\
\hline \multicolumn{9}{|l|}{ Age } \\
\hline Median (Range) & \multicolumn{2}{|c|}{$63(35-83)$} & \multicolumn{2}{|c|}{$64(43-85)$} & \multicolumn{2}{|c|}{$64(35-85)$} & \multicolumn{2}{|c|}{$66(25-90)$} \\
\hline \multicolumn{9}{|l|}{ Gender } \\
\hline Men & 95 & $55 \%$ & 24 & $48 \%$ & 119 & $54 \%$ & 132 & $62 \%$ \\
\hline Women & 77 & $45 \%$ & 26 & $52 \%$ & 103 & $46 \%$ & 82 & $38 \%$ \\
\hline \multicolumn{9}{|l|}{ Stage of disease } \\
\hline IIIB & 57 & $33 \%$ & 16 & $32 \%$ & 73 & $33 \%$ & 51 & $24 \%$ \\
\hline IV & 115 & $67 \%$ & 34 & $68 \%$ & 149 & $67 \%$ & 163 & $76 \%$ \\
\hline \multicolumn{9}{|l|}{ Performance status } \\
\hline 0 & 38 & $22 \%$ & 11 & $22 \%$ & 49 & $22 \%$ & 42 & $20 \%$ \\
\hline 1 & 88 & $51 \%$ & 31 & $62 \%$ & 119 & $54 \%$ & 130 & $61 \%$ \\
\hline 2 & 46 & $27 \%$ & 8 & $16 \%$ & 54 & $24 \%$ & 42 & $20 \%$ \\
\hline Appetite loss & 94 & $55 \%$ & 24 & $48 \%$ & 118 & $53 \%$ & 111 & $52 \%$ \\
\hline \multicolumn{9}{|l|}{ Histology } \\
\hline Adenocarcinoma & 76 & $44 \%$ & 26 & $52 \%$ & 102 & $46 \%$ & 112 & $52 \%$ \\
\hline Squamous cell carcinoma & 51 & $30 \%$ & 11 & $22 \%$ & 62 & $28 \%$ & 41 & $19 \%$ \\
\hline Large cell carcinoma & 9 & $5 \%$ & 2 & $4 \%$ & 11 & $5 \%$ & 13 & $6 \%$ \\
\hline Other & 36 & $21 \%$ & 11 & $22 \%$ & 47 & $21 \%$ & 48 & $22 \%$ \\
\hline \multicolumn{9}{|l|}{ Smoking history } \\
\hline Never smoker & 15 & $9 \%$ & 2 & $4 \%$ & 17 & $8 \%$ & 16 & $8 \%$ \\
\hline Former or current smoker & 157 & $91 \%$ & 48 & $96 \%$ & 205 & $92 \%$ & 196 & $92 \%$ \\
\hline \multicolumn{9}{|l|}{ Treatments } \\
\hline Pemetrexed/carboplatin & 85 & $49 \%$ & 24 & $48 \%$ & 109 & $49 \%$ & 110 & $51 \%$ \\
\hline Gemcitabine/carboplatin & 87 & $51 \%$ & 26 & $51 \%$ & 113 & $51 \%$ & 104 & $49 \%$ \\
\hline \multicolumn{9}{|l|}{ Cycles of chemotherapy } \\
\hline Mean & \multicolumn{2}{|c|}{3.1} & \multicolumn{2}{|c|}{3.4} & \multicolumn{2}{|c|}{3.2} & \multicolumn{2}{|c|}{3.3} \\
\hline \multicolumn{9}{|l|}{ Systemic second line therapy } \\
\hline Any & 51 & $30 \%$ & 19 & $38 \%$ & 70 & $32 \%$ & 65 & $30 \%$ \\
\hline Docetaxel & 16 & $9 \%$ & 7 & $14 \%$ & 23 & $10 \%$ & 29 & $14 \%$ \\
\hline Erlotinib & 12 & $7 \%$ & 7 & $14 \%$ & 19 & $9 \%$ & 12 & $6 \%$ \\
\hline Re-induction & 7 & $4 \%$ & 2 & $4 \%$ & 9 & $4 \%$ & 4 & $2 \%$ \\
\hline Carboplatin/vinorelbine & 7 & $4 \%$ & 2 & $4 \%$ & 9 & $4 \%$ & 10 & $5 \%$ \\
\hline Pemetrexed & 5 & $3 \%$ & - & - & 5 & $2 \%$ & 4 & $2 \%$ \\
\hline Other & 4 & $2 \%$ & 1 & $2 \%$ & 5 & $2 \%$ & 6 & $3 \%$ \\
\hline Systemic third line therapy & 10 & $6 \%$ & 2 & $4 \%$ & 12 & $5 \%$ & 18 & $8 \%$ \\
\hline
\end{tabular}

ER- $\alpha$ positive tumors had a significantly longer median survival than those with ER- $\alpha$ negative tumors (ER- $\alpha$ positive: 10.8 months, ER- $\alpha$ negative: 6.4 months; $p=0.008$ ). There was no significant difference in median overall survival between the treatment arms in the ER- $\alpha$ positive patients (PC: 11.2 months, GC: 8.8 months; $p=0.38$ ), but an interaction test revealed significantly different associations between treatment arms and survival for men and women in this subgroup $(p=0.004)$. Among women with ER- $\alpha$ positive tumors there was a substantial and highly significant difference (PC $(\mathrm{n}=13)$ : 20.0 months, GC $(n=13): 4.6$ months; $p=0.003)$. The survival difference was also significant when using cut-off values of $5 \%$ positive tumor cells ( $\mathrm{PC}(\mathrm{n}=11): 20.0, \mathrm{GC}(\mathrm{n}=13): 4.6$; $p=0.001)$ and $10 \%$ positive tumor cells (PC $(\mathrm{n}=8): 12.6$ months, GC ( $n=13)$ : 4.6 months; $p=0.026)$. Furthermore, the survival difference remained significant when excluding patients who received second line EGFR-TKI therapy (PC $(n=11): 20.0$ months, GC ( $n=11): 4.5$ months; $p=0.002)$ or all patients who received any second line systemic therapy (PC $(\mathrm{n}=7): 20.0$ months, GC ( $\mathrm{n}=8): 3.5$ months; $p=0.003)$.

Multivariate analyses adjusting for baseline characteristics previously identified as significant prognostic factors in the phase III study $(20,24)$ revealed that ER- $\alpha$ status $(H R=0.72$; $95 \% \mathrm{CI}=0.51-1.006 ; p=0.047)$ remained a significant positive prognostic factor in the overall population.

\section{Discussion}

We found that $23 \%$ of the tumors expressed ER- $\alpha$ and this was a significant positive prognostic factor, mainly due to 


\section{A}

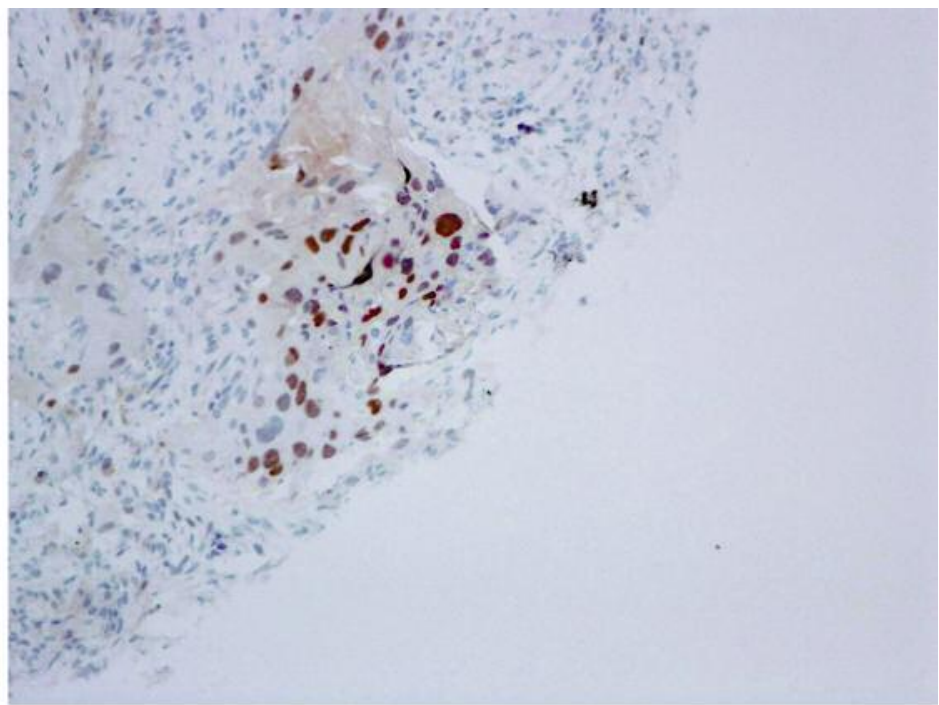

B

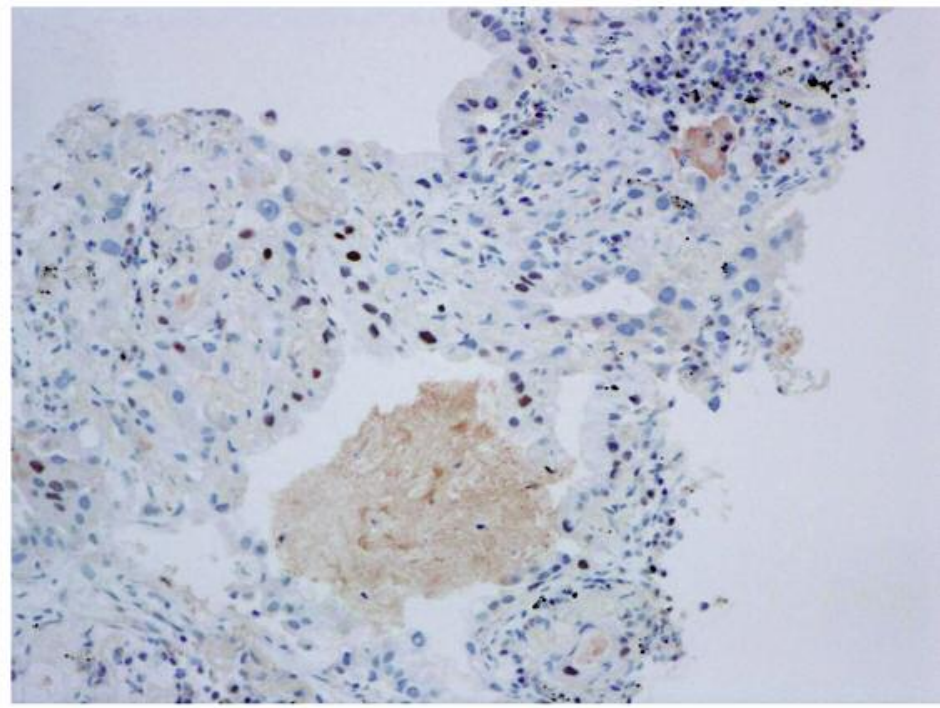

C

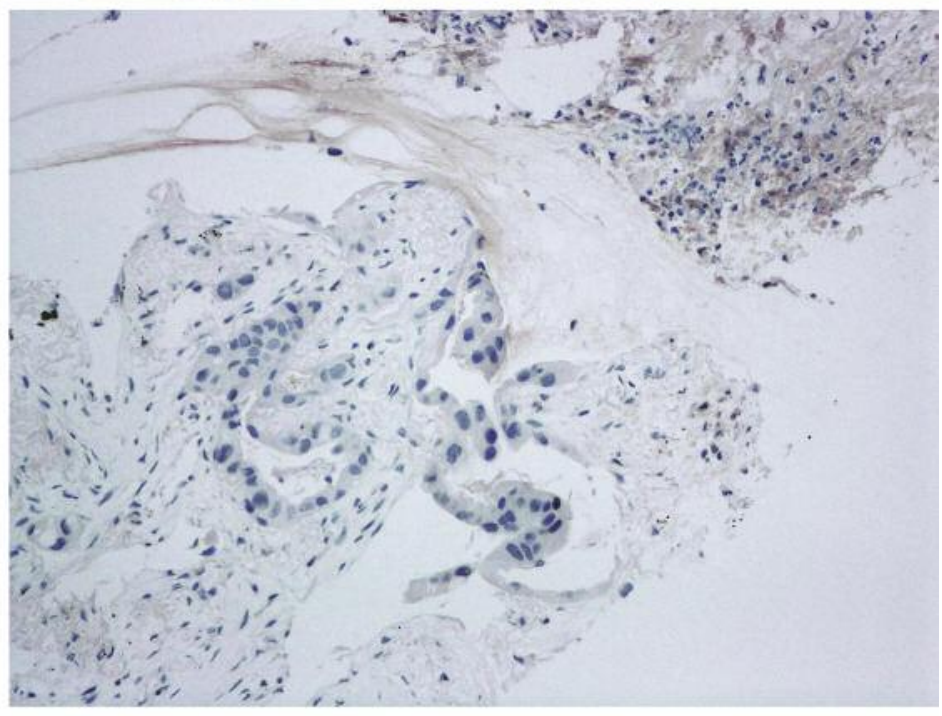

Figure 2. Patterns of nuclear staining of ER- $\alpha$ on $200 \times$ magnification. A and B: Brown staining indicates positive nuclei. C: Negative staining. 
A

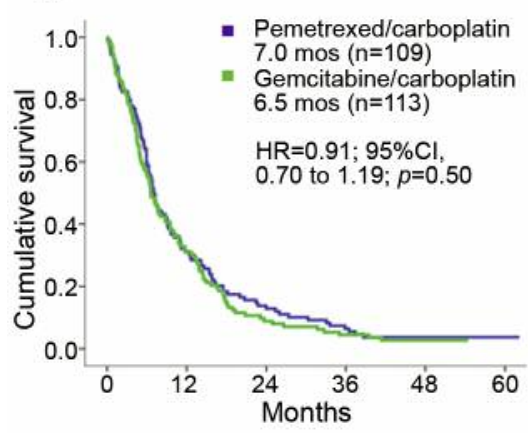

D

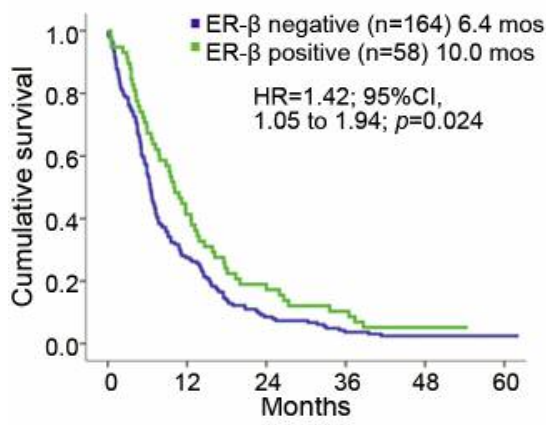

B

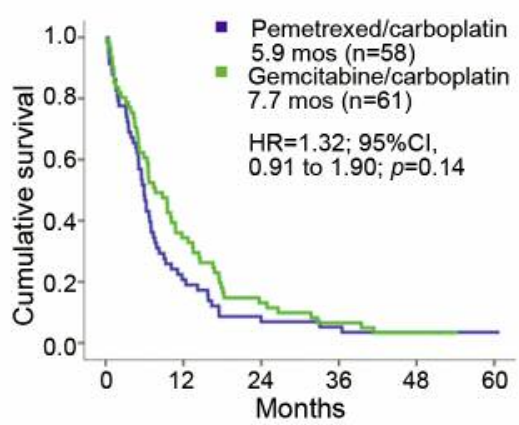

E

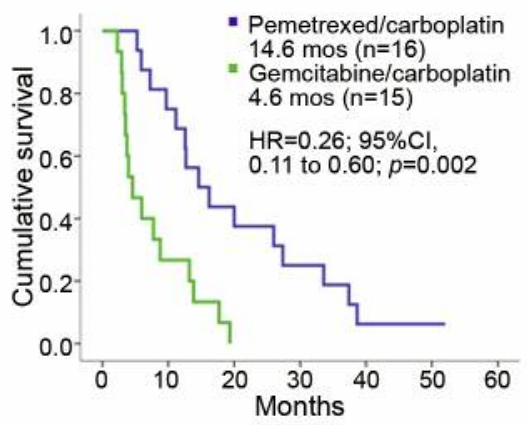

C

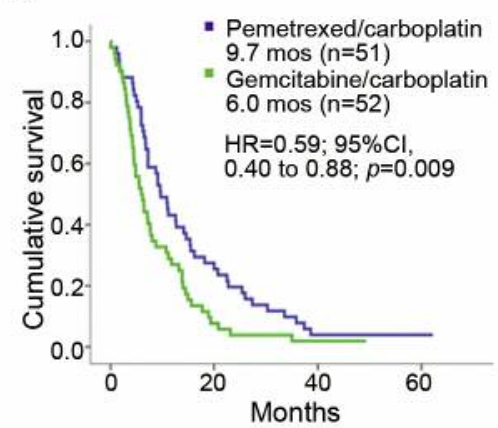

F

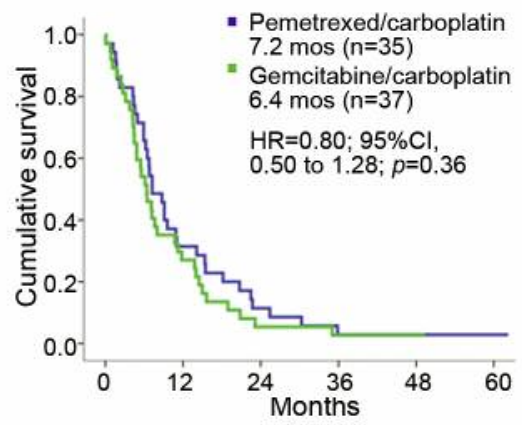

Figure 3. Survival depending on (A) study treatment among all patients, (B) study treatment among men, (C) study treatment among women, (D) ER- $\alpha$ status among all patients, $(E)$ study treatment among ER- $\alpha$ positive women, and $(F)$ study treatment among ER- $\alpha$ negative women.

the significant survival benefit of the pemetrexed-regimen among women with ER- $\alpha$ positive tumors.

We are not aware of other studies exploring associations between ER- $\alpha$ status, chemotherapy regimens and survival, but there are reports with varying results elaborating the incidence and prognostic role of ER- $\alpha$ in $\operatorname{NSCLC~}(6,15-18)$. One reason for the diverse results between studies might be the use of different antibody clones, lack of a standard method for assessment of ER- $\alpha$ and patient selection.

Our study is hampered by the absence of data regarding hormone replacement therapy. In addition, $26 \%$ of the cases were either classified as large cell carcinoma or "other" (Table I). According to the present diagnostic standards this is too high, but when the study was conducted (2005-2006), the clinical implications of sub-classification of NSCLC were not established. Unfortunately, there was not enough remaining tissue to reclassify the tumors with immunohistochemistry (IHC), nor test for EGFR, ALK, ROS1 or PD-L1 status.

Furthermore, most available tumor samples were small. Analyses of the few surgical resection specimens in our cohort revealed that IHC staining was not evenly expressed in all tumor cells, thus the expression of ER- $\alpha$ in biopsies might not be representative of the whole tumor, but the results remained significant when cutoff-values for ERpositivity of $5 \%$ and $10 \%$ were applied.

Pemetrexed is approved for first- and second-line treatment of non-squamous NSCLC, and recently also as maintenance therapy $(20,2,25-27)$. Despite the favorable toxicity profile and appealing survival benefit, there are concerns about providing maintenance therapy to all patients with advanced NSCLC. Not all patients benefit from such therapy; side effects might have a negative impact on quality of life; it is time-consuming, tiring and increases costs (28, 29). Thus, identifying biomarkers predicting pemetrexed sensitivity would have large clinical implications. Currently, no such biomarkers are routinely used. Inhibition of thymidylate synthase (TS) is the main mechanism of action of pemetrexed, and several studies show that pemetrexed is more effective in patients with low TS-levels than those with higher TS-level $(30,31)$, but also patients with high TSlevels respond to pemetrexed. In a previous study of the present cohort, we found that there was no difference in survival between patients receiving $\mathrm{PC}$ and those receiving GC depending on TS-level, possibly indicating that TS is a prognostic rather than a predictive marker in advanced NSCLC (32). 
Table II. Baseline characteristics of ER- $\alpha$ positive patients.

\begin{tabular}{|c|c|c|c|c|c|c|c|c|c|c|c|c|}
\hline & \multicolumn{2}{|c|}{$\begin{array}{l}\text { All ER- } \alpha \text { positive } \\
\text { women } \\
(n=26)\end{array}$} & \multicolumn{2}{|c|}{$\begin{array}{c}\text { ER- } \alpha \text { positive } \\
\text { women receiving } \\
\text { PC }(n=13)\end{array}$} & \multicolumn{2}{|c|}{$\begin{array}{c}\text { ER- } \alpha \text { positive } \\
\text { women receiving } \\
\text { GC }(n=13)\end{array}$} & \multicolumn{2}{|c|}{$\begin{array}{c}\text { All ER- } \alpha \text { positive } \\
\text { men } \\
(n=24)\end{array}$} & \multicolumn{2}{|c|}{$\begin{array}{l}\text { ER- } \alpha \text { positive } \\
\text { men receiving } \\
\text { PC }(n=11)\end{array}$} & \multicolumn{2}{|c|}{$\begin{array}{c}\text { ER- } \alpha \text { positive } \\
\text { men receiving } \\
\text { GC }(n=13)\end{array}$} \\
\hline & $\mathrm{n}$ & $\%$ & $\mathrm{n}$ & $\%$ & $\mathrm{n}$ & $\%$ & $\mathrm{n}$ & $\%$ & $\mathrm{n}$ & $\%$ & $\mathrm{n}$ & $\%$ \\
\hline \multicolumn{13}{|l|}{ Age } \\
\hline Median (Range) & \multicolumn{2}{|c|}{$62(43-85)$} & \multicolumn{2}{|c|}{$64(43-85)$} & \multicolumn{2}{|c|}{$60(50-71)$} & \multicolumn{2}{|c|}{$68(50-81)$} & \multicolumn{2}{|c|}{$68(50-77)$} & \multicolumn{2}{|c|}{$72(52-81)$} \\
\hline \multicolumn{13}{|l|}{ Stage } \\
\hline IIIB & 6 & $23 \%$ & 3 & $23 \%$ & 3 & $23 \%$ & 10 & $42 \%$ & 5 & $46 \%$ & 5 & $39 \%$ \\
\hline IV & 20 & $77 \%$ & 10 & $77 \%$ & 10 & $77 \%$ & 14 & $58 \%$ & 6 & $55 \%$ & 8 & $62 \%$ \\
\hline \multicolumn{13}{|l|}{ Performance status } \\
\hline 0 & 5 & $19 \%$ & 3 & $23 \%$ & 2 & $15 \%$ & 6 & $25 \%$ & 6 & $55 \%$ & - & - \\
\hline 1 & 18 & $69 \%$ & 10 & $77 \%$ & 8 & $62 \%$ & 13 & $54 \%$ & 3 & $27 \%$ & 10 & $77 \%$ \\
\hline 2 & 3 & $12 \%$ & - & - & 3 & $23 \%$ & 5 & $21 \%$ & 2 & $18 \%$ & 3 & $23 \%$ \\
\hline Appetite loss & 13 & $50 \%$ & 6 & $46 \%$ & 7 & $54 \%$ & 11 & $46 \%$ & 6 & $55 \%$ & 5 & $39 \%$ \\
\hline \multicolumn{13}{|l|}{ Histology } \\
\hline Adenocarcinoma & 13 & $50 \%$ & 6 & $46 \%$ & 7 & $54 \%$ & 13 & $54 \%$ & 7 & $64 \%$ & 6 & $46 \%$ \\
\hline Squamous cell carcinoma & 5 & $19 \%$ & 2 & $15 \%$ & 3 & $23 \%$ & 6 & $25 \%$ & 1 & $9 \%$ & 5 & $39 \%$ \\
\hline Large cell carcinoma & 3 & $12 \%$ & 2 & $15 \%$ & 1 & $8 \%$ & 2 & $8 \%$ & 1 & $9 \%$ & 1 & $8 \%$ \\
\hline Other & 5 & $19 \%$ & 3 & $23 \%$ & 2 & $15 \%$ & 3 & $13 \%$ & 2 & $18 \%$ & 1 & $8 \%$ \\
\hline \multicolumn{13}{|l|}{ Smoking history } \\
\hline Never smoker & 2 & $8 \%$ & 1 & $8 \%$ & 1 & $8 \%$ & - & - & - & - & - & - \\
\hline Former or current smoker & 24 & $92 \%$ & 12 & $92 \%$ & 12 & $92 \%$ & 24 & $100 \%$ & 11 & $100 \%$ & 13 & $100 \%$ \\
\hline \multicolumn{13}{|l|}{ Cycles of chemotherapy } \\
\hline Mean & 3.2 & 3.8 & 2.7 & 3.5 & 3.5 & 3.6 & & & & & & \\
\hline Any second line therapy & 11 & $42 \%$ & 6 & $46 \%$ & 5 & $62 \%$ & 8 & $33 \%$ & 3 & $27 \%$ & 5 & $39 \%$ \\
\hline Docetaxel & 5 & $19 \%$ & 2 & $15 \%$ & 3 & $23 \%$ & 2 & $8 \%$ & 2 & $18 \%$ & - & - \\
\hline Erlotinib & 4 & $15 \%$ & 2 & $15 \%$ & 2 & $15 \%$ & 3 & $13 \%$ & - & - & 3 & $23 \%$ \\
\hline Any third line therapy & 2 & $8 \%$ & 1 & $8 \%$ & 1 & $8 \%$ & - & - & - & - & - & - \\
\hline
\end{tabular}

PC: Pemetrexed plus carboplatin; GC: gemcitabine plus carboplatin.

The results of this study should be interpreted with caution. The sample size was limited, especially in the subgroup analyses. We are not aware of any convincing explanations for our observations, although one can speculate that the folatedependent enzyme, aminoimidazole-carboxamide ribonucleotide formyl-transferase (AICART), which is inhibited by pemetrexed, might have a role. Reduced AICART leads to elevated levels of AICAR monophosphate (ZMP) followed by activation of cAMP-dependent protein kinase (AMPK) (33). AMPK is a key factor in estrogen-dependent cell proliferation, and an increase of AMPK may lead to an increased progression of the cell cycle - which might increase sensitivity to pemetrexed and/or carboplatin in ER- $\alpha$ positive tumors. Another presumable explanation for the favorable outcome of the ER- $\alpha$ group is the affinity for platinum compounds in cells expressing ER- $\alpha$ (34). Neither of these theories explain the gender differences we found and based on our material we are not able to give any reasonable explanation for these differences.

Hsu et al. have reviewed several studies with ER as a prognostic marker in lung cancer (35), and found that there were referring to a variety of isoforms and scorings. These differences might partly explain conflicting results from different studies.
To the best of our knowledge, this study is the first to demonstrate a possible association between expression of ER$\alpha$, gender, and survival outcomes of different chemotherapy regimens in advanced NSCLC. With the known diversity among studies on ER receptors in lung carcinomas further research with standardized study design is crucial before the final clinical benefit of assessing ER- $\alpha$ can be established.

\section{Conclusion}

In conclusion, we found that ER- $\alpha$ was a significant prognostic factor for survival in advanced NSCLC. A survival benefit was seen in women treated with pemetrexed/carboplatin compared with gemcitabine/ carboplatin, mainly explained by a substantial survival advantage of the pemetrexed-regimen among the women with tumors expressing ER- $\alpha$.

\section{Conflicts of Interest}

Noah Theiss is an employee of Ventana Medical Systems (Roche). Bjørn H. Grønberg, Marius Lund-Iversen and Odd Terje Brustugun have received honoraria for lectures at meetings arranged by Eli Lilly and Company and Roche, and their travel expenses for 
Table III. Survival analyses.

\begin{tabular}{|c|c|c|c|c|c|c|c|}
\hline & $\begin{array}{l}\text { Median } \\
\text { (months) }\end{array}$ & $95 \% \mathrm{CI}$ & & $\begin{array}{l}\text { Median } \\
\text { (months) }\end{array}$ & $95 \% \mathrm{CI}$ & HR $(95 \% \mathrm{CI})$ & $p$-Value \\
\hline \multicolumn{8}{|l|}{ Age } \\
\hline$<75$ years $(n=184)$ & 6.8 & $5.8-7.8$ & $\geq 75$ years $(n=38)$ & 6.6 & $4.0-9.2$ & $0.91(0.64-1.29)$ & 0.59 \\
\hline \multicolumn{8}{|l|}{ Gender } \\
\hline Women $(n=103)$ & 7.2 & $5.4-9.1$ & Men (n=119) & 6.6 & $5.7-7.5$ & $0.89(0.68-1.16)$ & 0.37 \\
\hline \multicolumn{8}{|l|}{ Stage of disease } \\
\hline IIIB (n=73) & 6.4 & $5.4-7.5$ & IV $(n=149)$ & 7.4 & 7.8-9.0 & $1.18(0.89-1.57)$ & 0.25 \\
\hline \multicolumn{8}{|l|}{ Performance status } \\
\hline $0-1(n=168)$ & 7.4 & $5.8-9.0$ & $2(\mathrm{n}=54)$ & 5.1 & $3.4-6.8$ & $0.62(0.45-0.84)$ & 0.002 \\
\hline \multicolumn{8}{|l|}{ Appetite loss } \\
\hline No appetite loss $(n=104)$ & 10.0 & $8.5-11.5$ & Appetite loss $(\mathrm{n}=118)$ & 5.6 & $4.6-6.5$ & $0.59(0.45-0.78)$ & $<0.001$ \\
\hline \multicolumn{8}{|l|}{ Histology } \\
\hline Squamous cell carcinoma $(n=62)$ & 7.2 & $5.8-8.7$ & Adeno- and large cell carcinoma (113) & 7.1 & $5.7-8.5$ & $1.18(0.86-1.62)$ & 0.31 \\
\hline \multicolumn{8}{|l|}{ Smoking history } \\
\hline Never-smoker $(n=17)$ & 7.2 & $3.7-10.7$ & Ever-smoker $(\mathrm{n}=205)$ & 6.8 & $6.0-7.7$ & $1.12(0.67-1.86)$ & 0.67 \\
\hline \multicolumn{8}{|l|}{ ER- $\alpha$ status } \\
\hline ER- $\alpha$ negative $(n=172)$ & 6.4 & $5.7-7.2$ & ER- $\alpha$ positive $(n=50)$ & 10.8 & $8.1-13.5$ & $1.55(1.12-2.15)$ & 0.008 \\
\hline \multicolumn{8}{|l|}{ Chemotherapy } \\
\hline Pemetrexed/carboplatin $(n=109)$ & 7.0 & $6.0-8.0$ & Gemcitabine/carboplatin $(n=113)$ & 6.6 & $5.2-8.0$ & $0.91(0.70-1.19)$ & 0.50 \\
\hline \multicolumn{8}{|l|}{ Men } \\
\hline Pemetrexed/carboplatin $(\mathrm{n}=58)$ & 5.9 & $5.1-6.7$ & Gemcitabine/carboplatin $(\mathrm{n}=61)$ & 7.7 & $4.9-10.5$ & $1.32(0.91-1.90)$ & 0.14 \\
\hline \multicolumn{8}{|l|}{ Women } \\
\hline Pemetrexed/carboplatin $(\mathrm{n}=51)$ & 9.7 & $7.3-12.1$ & Gemcitabine/carboplatin $(n=52)$ & 6.0 & $4.1-7.9$ & $0.59(0.40-0.88)$ & 0.009 \\
\hline \multicolumn{8}{|l|}{ ER- $\alpha$ positive women } \\
\hline Pemetrexed/carboplatin $(n=13)$ & 20.0 & $4.2-35.8$ & Gemcitabine/carboplatin $(\mathrm{n}=13)$ & 4.6 & $2.0-7.2$ & $0.22(0.08-0.59)$ & 0.003 \\
\hline \multicolumn{8}{|l|}{ ER- $\alpha$ positive men } \\
\hline Pemetrexed/carboplatin $(n=11)$ & 7.8 & $2.9-12.8$ & Gemcitabine/carboplatin $(n=13)$ & 11.7 & 7.6-15.9 & $1.66(0.72-3.85)$ & 0.24 \\
\hline \multicolumn{8}{|l|}{ ER- $\alpha$ negative women } \\
\hline Pemetrexed/carboplatin $(n=38)$ & 8.8 & $6.0-11.5$ & Gemcitabine/carboplatin $(n=39)$ & 6.4 & $4.5-8.4$ & $0.77(0.49-1.21)$ & 0.26 \\
\hline \multicolumn{8}{|l|}{ ER- $\alpha$ negative men } \\
\hline Pemetrexed/carboplatin $(n=47)$ & 5.6 & $4.5-6.8$ & Gemcitabine/carboplatin $(n=48)$ & 6.6 & $4.1-9.1$ & $1.19(0.79-1.79)$ & 0.42 \\
\hline No second-line therapy $(n=152)$ & 5.1 & 4.3-5.9 & Any second-line therapy $(n=152)$ & 14.0 & $10.5-17.5$ & $1.98(1.48-2.66)$ & $<0.001$ \\
\hline
\end{tabular}

attending international oncology meetings have previously been paid by Eli Lilly Company and Roche. Erik H. Strøm and Helge Scott do not have any disclosures.

\section{Acknowledgements}

The Authors wish to thank all investigators in the phase III trial; Scott Myrand at Eli Lilly and Company who helped designing the study; Ingjerd Solvoll and Ellen Hellesylt at the Oslo University Hospital - Radiumhospitalet who organized collection of the tumor samples and made the slides; Eric Powell who previously worked at Ventana Medical Systems Inc. and trained the pathologist in reading the slides; Eli Lilly and Company who supported the study and Professor Aasmund Berner for constructive comments to the manuscript. Eli Lilly and Company supported the study with an unrestricted grant and paid Ventana Medical Systems for training of the pathologists and assistance with staining the slides.

\section{References}

1 Wheatley-Price P, Blackhall F, Lee SM, Ma C, Ashcroft L, Jitlal M, Qian W, Hackshaw A, Rudd R, Booton R, Danson S, Lorigan
P, Thatcher N and Shepherd FA: The influence of sex and histology on outcomes in non-small-cell lung cancer: a pooled analysis of five randomized trials. Ann Oncol 21: 2023-2028, 2010.

2 Wakelee HA, Wang W, Schiller JH, Langer CJ, Sandler AB, Belani CP and Johnson DH: Eastern Cooperative Oncology Group: Survival differences by sex for patients with advanced non-small cell lung cancer on Eastern Cooperative Oncology Group trial 1594. J Thorac Oncol 1: 441-446, 2006.

3 Sagerup CM, Smastuen M, Johannesen TB, Helland A and Brustugun OT: Sex-specific trends in lung cancer incidence and survival: a population study of 40,118 cases. Thorax 66: 301307, 2011.

4 Wu CT, Chang YL, Shih JY and Lee YC: The significance of estrogen receptor beta in 301 surgically treated non-small cell lung cancers. J Thorac Cardiovasc Surg 130: 979-986, 2005.

5 Schwartz AG, Prysak GM, Murphy V, Leonardo G, Pass H, Schwartz J and Brooks S: Nuclear estrogen receptor beta in lung cancer: expression and survival differences by sex. Clin Cancer Res 11: 7280-7287, 2005.

6 Skov BG, Fischer BM and Pappot H: Oestrogen receptor beta over expression in males with non-small cell lung cancer is associated with better survival. Lung Cancer 59: 88-94, 2008. 
7 Lother SA, Harding GA, Musto G, Navaratnam S and Pitz MW: Antiestrogen use and survival of women with non-small cell lung cancer in Manitoba, Canada. Hormones Cancer 4: 270-276, 2013.

8 Chlebowski RT, Schwartz AG, Wakelee H, Anderson GL, Steganick ML, Manson JE, Rodabough RJ, Chien JW, Wactawski-Wende J, Gass M, Kotchen JM, Johnson KC, O'Sullivan MJ, Ockene JK, Chen C and Hubbel FA: Oestrogen plus progestin and lung cancer in postmenopausal women (Women's Health Initiative trial): a post-hoc analysis of a randomised controlled trial. Lancet 374: 1243-1251, 2009.

9 Dougherty SM, Mazhawidza W, Bohn AR, Robinson KA, Mattingly KA, Blankenship KA, Huff MO, McGregor WG and Klinge CM: Gender difference in the activity but not expression of estrogen receptors alpha and beta in human lung adenocarcinoma cells. Endocr Relat Cancer 13: 113-134, 2006.

10 Ivanova MM, Mazhawidza W, Dougherty SM and Klinge CM: Sex differences in estrogen receptor subcellular location and activity in lung adenocarcinoma cells. Am J Respir Cell Mol Biol 42: 320-330, 2010.

11 Siegfried JM and Stabile LP: Estrongenic steroid hormones in lung cancer. Semin Oncol 41: 5-16, 2014.

12 Monica V, Longo M, Felice B, Scagliotti GV, Papotti M and Novello S: Role of hormone receptor expression in patients with advanced-stage lung cancer treated with chemotherapy. Clin Lung Cancer 13: 416-423, 2012.

13 Verma MK, Miki Y, Abe K, Nagasaki S, Niikawa H, Suzuki S, Kondo T and Sasano H: Co-expression of estrogen receptor beta and aromatase in Japanese lung cancer patients: genderdependent clinical outcome. Life Sci 91: 800-808, 2012.

14 Stabile LP, Dacic S, Land SR, Lenzner DE, Dhir R, Ackuafondata M, Landreneau RJ, Grandis JR and Siegfried JM: Combined analysis of estrogen receptor beta- 1 and progesterone receptor expression identifies lung cancer patients with poor outcome. Clin Cancer Res 17: 154-164, 2011.

15 Kawai H, Ishii A, Washiya K, Konno T, Kon H, Yamaya C, Ono I, Minamyia Y and Ogawa J: Estrogen receptor alpha and beta are prognostic factors in non-small cell lung cancer. Clin Cancer Res 11: 5084-5089, 2005.

16 Rades D, Setter C, Dahl O, Schild SE and Noack F: The prognostic impact of tumor cell expression of estrogen receptoralpha, progesterone receptor, and androgen receptor in patients irradiated for nonsmall cell lung cancer. Cancer 118: 157-163, 2012.

17 Rouquette I, Lauwers-Cances V, Allera C, Brouchet L, Milia J, Nicaise Y, Laurent J, Delisle MB, Favre, Didier A and Mazières $\mathrm{J}$ : G Characteristics of lung cancer in women: importance of hormonal and growth factors. Lung Cancer 76: 280-285, 2012.

18 Nose N, Sugio K, Oyama T Nozoe T, Uramoto H, Iwata T, Onitsuka $\mathrm{T}$ and Yasumoto $\mathrm{K}$ : Association between estrogen receptor-beta expression and epidermal growth factor receptor mutation in the postoperative prognosis of adenocarcinoma of the lung. J Clin Oncol 27: 411-417, 2009.

19 Azzoli CG, Baker S Jr., Temin S, Pao W, Aliff T, Brahmer J, Johnson DH, Laskin JL, Masters G, Milton D, Nordquist L, Pfister DG, Piantadosi S, Schiller, JH, Smith R, Smith TJ, Strawn JR, Trent D and Giaccone G: American Society of Clinical Oncology Clinical Practice Guideline update on chemotherapy for stage IV non-small-cell lung cancer. J Clin Oncol 27: 6251-6266, 2009.
20 Grønberg BH, Bremnes RM, Fløtten $\varnothing$, Amundsen T, Brunsvig PF, Hjelde HH, Kaasa S, von Plessen C, Stornes F, Tollåli T, Wammer F, Aaseb $\varnothing$ U and Sundstrøm S: Phase III study by the Norwegian Lung Cancer Study Group: Pemetrexed plus carboplatin compared with gemcitabine plus carboplatin as firstline chemotherapy in advanced non-small-cell lung cancer. $\mathrm{J}$ Clin Oncol 27: 3217-3224, 2009.

21 Scagliotti GV, Parikh P, von Pawel J, Biesma B, Vansteenkiste J, Manegold C, Serwatowski P, Gatzemeier U, Digumarti R, Zukin M, Lee JS, Mellemgard A, Park K, Patil S, Rolski J, Goksel T, de Marinis F, Simms L, Sugarman KP and Gandara D: Phase III study comparing cisplatin plus gemcitabine with cisplatin plus pemetrexed in chemotherapy-naive patients with advanced-stage non-small-cell lung cancer. J Clin Oncol 26: 3543-3551, 2008.

22 Kadota K, Eguchi T, Villena-Vargas J, Woo KM, Sima CS, Jones DR, Travis WD and Adusumilli PS: Nuclear estrogen receptor$\alpha$ expression is an independent predictor of recurrence in male patients with pT1aN0 lung adenocarcinomas, and correlates with regulatory T-cell infiltration. Oncotarget 6: 27505-27517, 2015.

23 Harvey JM, Clark GM, Osborne CK and Allred DC: Estrogen receptor status by immunohistochemistry is superior to the ligand-binding assay for predicting response to adjuvant endocrine therapy in breast cancer. J Clin Oncol 17: 1474-1481, 1999.

24 Gronberg BH, Sundstrom S, Kaasa S, Bremnes RM, Fløtten O, Amundsen T, Hjelde HH, Plessen CY and Jordhøy M: Influence of comorbidity on survival, toxicity and health-related quality of life in patients with advanced non-small-cell lung cancer receiving platinum-doublet chemotherapy. Eur J Cancer 46: 2225-2234, 2010.

25 Hanna N, Shepherd FA, Fossella FV, Pereira JR, De Marinis F, von Pawel J, Gatzemeier U, Tsao TC, Pless M, Muller T, Lim HL, Desch C, Szondy K, Gervais R, Shaharyar, Manegold C, Paul S, Paoletti P, Einhorn L and Bunn PA Jr.: Randomized phase III trial of pemetrexed versus docetaxel in patients with non-small-cell lung cancer previously treated with chemotherapy. J Clin Oncol 22: 1589-1597, 2004.

26 Ciuleanu T, Brodowicz T, Zielinski C, Kim JH, Krzakowski M, Laack E, Wu YL, Bover I, Begbie S, Tzekova V, Cucivic B, Pareira JR, Yang SH, Madhavan J, Sugarman KP, Peterson P, John WJ, Krejcy K and Belani CP: Maintenance pemetrexed plus best supportive care versus placebo plus best supportive care for non-small-cell lung cancer: a randomised, double-blind, phase 3 study. Lancet 374: 1432-1440, 2009.

27 Paz-Ares L, de Marinis F, Dediu M, Thomas M, Pujol JL, Bidoli P, Molinier O, Sahoo TP, Laack E, Reck M, Corral J, Melemed S, John W, Chouaki N, Zimmermann AH, Visseren-Grul C and Gridelli C: Maintenance therapy with pemetrexed plus best supportive care versus placebo plus best supportive care after induction therapy with pemetrexed plus cisplatin for advanced non-squamous non-small-cell lung cancer (PARAMOUNT): a double-blind, phase 3, randomised controlled trial. Lancet Oncol 13: 247-255, 2012

28 Gerber DE and Schiller JH: Maintenance chemotherapy for advanced non-small-cell lung cancer: new life for an old idea. $\mathrm{J}$ Clin Oncol 31: 1009-1020, 2013.

29 Edelman MJ, Le Chevalier T and Soria JC: Maintenance therapy and advanced non-small-cell lung cancer: a skeptic's view. J Thorac Oncol 7: 1331-1336, 2012. 
30 Chen CY, Chang YL, Shih JY, Lin JW, Chen KY, Yang CH, Yu CJ and Yang PC: Thymidylate synthase and dihydrofolate reductase expression in non-small cell lung carcinoma: the association with treatment efficacy of pemetrexed. Lung Cancer 74: 132-138, 2011.

31 Sun JM, Han J, Ahn JS, Park K and Ahn MJ: Significance of thymidylate synthase and thyroid transcription factor 1 expression in patients with nonsquamous non-small cell lung cancer treated with pemetrexed-based chemotherapy. J Thorac Oncol 6: 1392-1399, 2011.

32 Gronberg BH, Lund-Iversen M, Strøm EH, Brustugun OT and Scott H: Associations between TS, TTF-1, FR-alpha, FPGS, and overall survival in patients with advanced non-small-cell lung cancer receiving pemetrexed plus carboplatin or gemcitabine plus carboplatin as first-line chemotherapy. $\mathrm{J}$ Thorac Oncol 8: 1255-1264, 2013.
33 Racanelli AC, Rothbart SB, Heyer CL and Moran RG: Therapeutics by cytotoxic metabolite accumulation: pemetrexed causes ZMP accumulation, AMPK activation, and mammalian target of rapamycin inhibition. Cancer Res 69: 5467-5474, 2009.

34 Saha P, Descôteaux C, Brasseur K, Fortin S, Leblanc V, Parent S, Asselin E and Bérubé G: Synthesis, antiproliferative activity and estrogen receptor $\alpha$ affinity of novel estradiol-linked platinum(II) complex analogs to carboplatin and oxaliplatin. Potential vector complexes to target estrogen-dependent tissues. Eur J Med Chem 48: 385-90, 2012.

35 Hsu LH, Chu NM and Kao SH: Estrogen, estrogen receptor and lung cancer. Int J Mol Sci 18, 2017. doi: 10.3390/ijms18081713.

Received February 13, 2018

Revised March 2, 2018

Accepted March 5, 2018 